\section{Pecan Orchard Renewal: Influence of Established Trees and Remaining Stumps on Transplant Growth and Crown Gall Infection}

\author{
Michael W. Smith ${ }^{1,4}$ \\ Department of Horticulture and Landscape Architecture, 360 Agricultural \\ Hall, Oklahoma State University, Stillwater, OK 74078
}

William D. Goff ${ }^{2}$

Department of Horticulture, 118 Extension Hall, Auburn University, AL 36849

\author{
M. Lenny Wells ${ }^{3}$ \\ Department of Horticulture, University of Georgia, 4604 Research Way, \\ Tifton, GA 31793
}

Additional index words. Carya illinoinensis, Agrobacterium tumefaciens, interplant, competition

\begin{abstract}
The productive life of a pecan [Carya illinoinensis (Wangenh.) K. Koch] orchard frequently spans two or more generations, but eventually orchards require renewal. Weather events damage tree canopies, pests affect tree health and productivity, and new cultivars offer greater yield potential or better nut quality. A popular method of orchard renewal is selective tree removal combined with interplanting new trees. Many old pecan orchards in the southeastern United States are infected with crown gall [Agrobacterium tumefaciens (Smith and Townsend) Conn.], potentially a problem for interplanted trees. Two tree types, nursery-grafted trees and seedling trees that were grafted 3 years after transplanting, were evaluated 6 years after transplanting. Transplanted trees varied in distances from established 80-year-old trees or residual stumps after tree removal. Ten trees near the study site, located $3.6 \mathrm{~m}$ from crown gall-infected stumps, were excavated to determine disease incidence. No crown gall was observed on any of the 87 trees in the study or the excavated trees. Trunk diameters of interplanted trees increased as distance from the nearest stump decreased and distance from the nearest established tree increased. Leaf elemental concentrations of the 6-year-old transplants were not related to observed growth differences. Conclusions include 1) stumps promoted rapid transplant growth; 2) crown gall infections of transplanted trees were unlikely even when crown gall symptoms were obvious on adjacent trees and stumps; and 3) transplant growth was suppressed by established trees.
\end{abstract}

Georgia is the largest pecan producer in the United States (U.S. Department of Agriculture, 2009). A substantial amount of Georgia's production is from orchards planted 60 to 100 years ago. Typically, these orchards were

Received for publication 13 Feb. 2013. Accepted for publication 2 Apr. 2013.

Funded by the Oklahoma Agricultural Experiment Station, Alabama Agricultural Experiment Station, Georgia Agricultural Experiment Station, Friendship Pecan Farm, Baconton, GA; Merritt Pecan Company, Weston, GA; and High Hopes Pecans, Weston, GA.

We gratefully acknowledge the support and assistance of Becky Cheary, O.S.U. Senior Agriculturist. Approved for publication by the Oklahoma Agricultural Experiment Station, AL Agricultural Experiment Station, and Georgia Agricultural Experiment Station.

${ }^{1}$ Regents Professor.

${ }^{2}$ Nunn Bond Professor and Extension Horticulturist. ${ }^{3}$ Associate Professor.

${ }^{4}$ To whom reprint requests should be addressed; e-mailmike.smith@okstate.edu.
Cultivar pecan orchards are started by planting seed at the desired orchard spacing to produce a rootstock followed by grafting to acceptable cultivars, planting nurseryproduced seedlings at orchard spacings followed by grafting or planting nursery-grafted trees (rootstock grafted to scion cultivar). Some advantages and disadvantages are obvious for each tree type. For instance, seed or seedlings are inexpensive, decisions regarding the scion cultivar can be delayed, and limited availability of the preferred cultivar is avoided (normally graft or bud wood is not limiting). Disadvantages include the expense of grafting and, depending on the skill of those involved, may require 3 or more years to successfully graft all seedlings. The time required to begin production may be longer using seed or seedlings. One significant advantage, particularly in northern production areas, of establishing seedlings and then grafting is greater cold-hardiness when grafted higher on the rootstock trunk (Sparks and Payne, 1977). Observations also suggest most seedling trunks (juvenile growth) are less prone to damage than cultivar trunks (adult phase growth) when mechanically thinning fruit. In hurricane-prone areas of the Southeast, whip-grafted trees that are grafted near or below ground level are frequently planted too deep resulting in poor anchorage and are subject to wind-throw.

Data are unavailable comparing pecan orchard renovation with grafted vs. seedling trees; however, one study compared seed, seedling, and grafted pecan trees when establishing a new orchard (Thompson et al., 1982). Pecan yields during initial production were similar 3 of 5 years for trees started from seed, 1- or 3-year-old seedlings that were budded their third growing season, and nurserybudded trees. In walnut (Juglans regia L.), cumulative yield ( 8 years) was greater using grafted trees or planting seed and then grafting to the desired cultivar than those planted as seedlings and then grafted (Reil, 2001).

One problem encountered with interplanted pecan trees was a symptom called "mouse-ear or little-leaf," a disorder formerly thought to be a manganese shortage (Gammon and Sharpe, 1956). In its most severe form, young trees were severely stunted and unproductive. Wood et al. (2004a, 2004b) conclusively demonstrated that mouse-ear was caused by nickel deficiency. Routine foliar application of a commercially available nickel product eliminated this problem.

Crown gall has the broadest host range of any plant pathogen with over 600 characterized plant hosts (DeCleene and Deley, 1976). This disease is widespread in most old Georgia pecan orchards with $25 \%$ to $60 \%$ of the trees infected (Bouzar et al., 1983). Galled trees are stunted and less productive. Diseased trees may have resulted from contaminated nursery stock (Moore, 1976) or the soil inhabiting bacterium was present when trees were planted. A common weed control practice before herbicides came into widespread use was soil disking. This practice 
repeatedly wounded roots increasing the likelihood of infection (Formica, 1989) and probably contributed to the pervasive infection common in these old orchards (Bouzar et al., 1983).

Removal of old trees is accomplished using several options. These range from removal with a chainsaw, tree cutter, bulldozer, or track hoe. Removal with a chainsaw or tree cutter leaves the stump and roots intact, whereas a bulldozer or track hoe removes the stump and a portion of the root system.

No data are available regarding performance of transplanted trees into an existing orchard. Concerns include transfer of crown gall from stumps of removed trees or remaining old trees and negative impacts of stumps or remaining trees on growth of transplanted trees. Because renovation practices include the use of nursery grafted trees and seedling trees grafted after establishment, both tree types were included in the study. We report performance of transplanted trees before production.

\section{Materials and Methods}

The study site was located $\approx 8 \mathrm{~km}$ south of Albany, GA (lat. $31^{\circ} 30^{\prime} \mathrm{N}$, long. 845' W) on an Orangeburg loamy sand (fine-loamy, kaolinitic, thermic Typic Kandiudults). The existing orchard, spaced $14.2 \mathrm{~m} \times 14.2 \mathrm{~m}$, was crowded and consisted of a mixture of cultivars, primarily Stuart, Schley, Moore, Pabst, Moneymaker, and Teche cultivars with varying degrees of desirability for commercial production. Established pecan trees $\approx 80$ years old were evaluated using cultivar desirability (current knowledge of productivity, kernel percentage, alternate bearing, nut size, and disease susceptibility), tree health (canopy bearing surface, crown gall infestation, and trunk injury), and canopy width (crowding evaluation) to determine those for elimination to reduce crowding, thus improving orchard production characteristics (Goff and Browne, 2004). This resulted in variable spacings of established trees. Tree removal allowed planting desirable cultivars, thus renewing the orchard while maintaining substantial production.

The orchard floor vegetation cover was white clover (Trifolium repens L.) in the row middles with a vegetation-free strip $3.6 \mathrm{~m}$ wide centered on the trees that ran the length of the row and managed with a combination of herbicides. Vegetation competing with clover was controlled using a weed-wiper (herbicides dispensed to vegetation by contact with herbicide-saturated cloth) and occasional mowing. Trees were irrigated as required based on owner/manager judgment using solid set sprinklers. Transplanted trees and established trees received the same fertilizer and irrigation treatment. The fertility program relied on leaf elemental analysis to guide fertility practices. Typically, $112 \mathrm{~kg} \cdot \mathrm{ha}^{-1}$ nitrogen, $14.6 \mathrm{~kg} \cdot \mathrm{ha}^{-1}$ phosphorus, and $56 \mathrm{~kg} \cdot \mathrm{ha}^{-1}$ potassium were applied in the vegetation free strip during August in years with bountiful production (on years); otherwise, no fertilizer was applied. Zinc was foliarly applied using zinc sulfate $(36 \% \mathrm{Zn})$ at $1.2 \mathrm{~g} \cdot \mathrm{L}^{-1}$ approximately five times annually.

Trees were removed during the winter of 2005-06 using a tree cutter and skidder (tree removal for disposal) commonly used in the logging industry. The stump, $\approx 0.5 \mathrm{~m}$ tall, remained intact. 'Creek' trees on Elliott seedling rootstocks and seedlings produced from field-run seed of advanced breeding line selections and desirable cultivars were planted during the same winter-established trees were removed. 'Creek' trees were $1.2 \mathrm{~m}$ to $1.5 \mathrm{~m}$ tall when transplanted, and seedlings were $0.5 \mathrm{~m}$ to $0.6 \mathrm{~m}$ tall. Seedling trees were grafted to 'Creek' using the four-flap technique 3 years after transplanting. If the graft failed, trees were budded in August or September of the same year and the bud forced the next growing season.

The experimental site consisted of 39 nursery grafted trees and 48 seedling trees. The distance from nearest established tree $(10.7 \mathrm{~m}$ to $24.9 \mathrm{~m})$ and from a stump (3.6 $\mathrm{m}$ to $28.7 \mathrm{~m}$ ) (Fig. 1) varied for both tree types. Approximately $40 \%$ of the established trees and stumps were infected with crown gall.

Trunk diameter was measured $70 \mathrm{~cm}$ above the ground while trees were dormant in Mar. 2012. Transplanted trees were visually inspected for crown gall in Jan. 2013. In addition, 10 trees from adjacent rows within $3.6 \mathrm{~m}$ of an infested stump were excavated to inspect the crown and roots for the presence of crown gall.

Leaf samples from individual trees were collected in July 2012 for elemental analysis. The index tissue was the middle leaflet pair from the middle leaf on current-season shoots. Samples were sealed in a plastic bag and sent overnight to a laboratory where they were washed in tap water followed by phosphorus-free detergent solution and two deionized water rinses. Samples were blotted dry and then dried in a forced-air oven at $60^{\circ} \mathrm{C}$, ground to pass an $850-\mu \mathrm{m}$ screen, and stored for later analysis. Leaf elemental concentrations of nitrogen $(\mathrm{N})$ were determined after additional grinding of samples in a Cyclotec mill followed by analysis with a Leco $\mathrm{N}$ analyzer (Leco, St. Joseph, MI) (Yoemans and Bremner, 1991). Samples were ashed in a muffle furnace at $500{ }^{\circ} \mathrm{C}$, dissolved in $20 \%$ hydrochloric acid, filtered through Whatman 41 filter paper, and brought to the appropriate dilution with a $2 \%$ lanthanum solution. Phosphorus $(\mathrm{P})$ was determined colorimetrically (Olsen and Sommers, 1982). Potassium (K), calcium $(\mathrm{Ca})$, magnesium $(\mathrm{Mg})$, copper, iron $(\mathrm{Fe})$, zinc $(\mathrm{Zn})$, and manganese $(\mathrm{Mn})$ were analyzed using atomic absorption spectroscopy (Model 2380; Perkin Elmer, Waltham, MA) (David, 1958).

Data were analyzed using regression analysis. Independent variables were tree type (grafted vs. seedling), distance to the nearest established tree, and distance to the nearest stump. Data were analyzed using least square techniques (Draper and Smith, 1966). The main effects and interactions of the three independent variables were tested using type one and three sum of squares. The significance level using both model types was similar indicating a reasonable independence of the independent variables. Linear and quadratic components of the distance to either an established tree or stump were tested. An appropriate model was selected based on retaining variables significant at the $5 \%$ level or greater.

\section{Results}

Crown gall was not observed on any of the trees in the study or any of the excavated trees. The authors have observed hundreds of trees transplanted among crown gallinfected trees or stumps and the incidence of an infected transplant was extremely rare. In some cases, young trees were planted immediately adjacent to the stump without apparent infection.

Removal of established trees was based on criteria outlined by Goff and Browne (2004) resulting in a random pattern of established trees and stumps with young interplanted trees. The distances from the interplanted trees to the nearest stump and to the nearest established tree were not inversely related. For instance, in some cases, a single tree was removed; thus, the distance to the nearest stump might be in the row where the tree was removed but the nearest established tree might be in the adjacent row or the same row. If three adjacent trees were

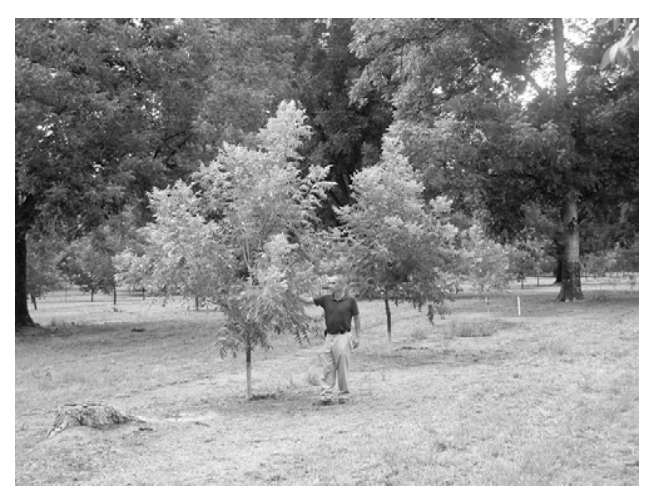

Fig. 1. Representative picture of remaining stump 7 years after tree removal, transplanted trees in their seventh growing season, and residual established tree. 
removed in a row and a tree removed in the adjoining row, it again results in no relationship between distance to the nearest stump and established tree. The lack of relationship between independent variables distances to the nearest stump and established tree is supported by tests using type one and three sums of squares indicating independence of the variables.

Trunk diameters of nursery-grafted trees were larger than seedling trees when grown at the same distances from stumps and existing trees (Fig. 2). Trunk diameter of nurserygrafted trees averaged 28\% larger than those of seedlings when pooled over distance from stumps and established trees. The lack of interaction between tree type (grafted vs. seedling) and distance to a stump or existing tree indicates that although grafted trees were larger when planted and retained the size advantage, the smaller seedlings grew equally well when exposed to competition from established trees or stumps.

Established trees slowed growth of both tree types (Fig. 2). Trunk diameter of transplanted trees decreased linearly as the distance
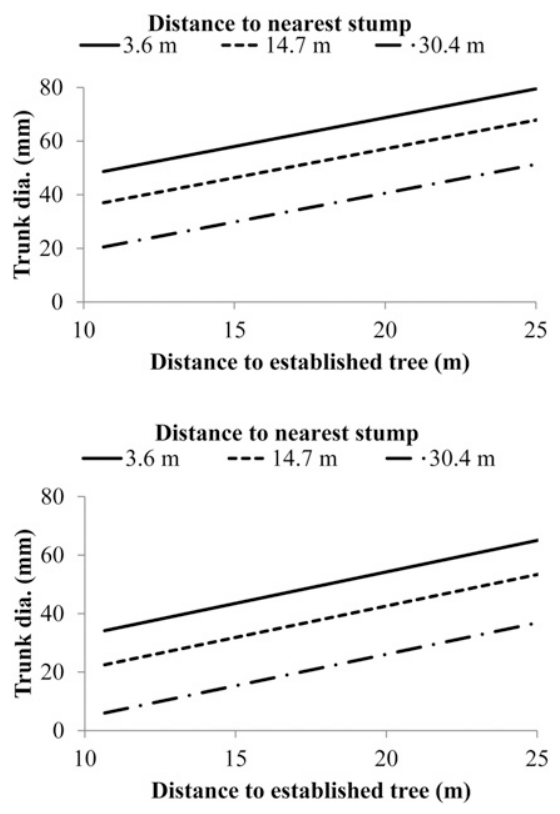

Fig. 2. The relationship of transplanted nurserygrafted trees (top graph) and seedling trees (bottom graph) trunk diameters 7 years after planting with the distance to the nearest established 80-year-old pecan trees and pecan stumps removed the year of planting. The main effect ( $\mathrm{Y}$ intercept) of tree type (seedling vs. grafted) was significant $(P=0.001)$, but the interaction between tree type with distance to established tree or stump was not significant nor was the interaction between distance to established tree and stump. The linear components of distance to established tree $(P=$ $0.0003)$ and stump $(P=0.0001)$ were significant as well as the entire model $(P=0.0001)$. Equations are nursery grafted $\hat{\mathrm{Y}}=29.5-1.05 \mathrm{~S}+$ $2.15 \mathrm{~T}$ and seedling $\hat{\mathrm{Y}}=15.0-1.05 \mathrm{~S}+2.15 \mathrm{~T}$ where $\hat{\mathrm{Y}}$ is the estimated trunk diameter of the transplanted tree, $\mathrm{S}$ is the distance to the nearest stump in meters, and $\mathrm{T}$ is the distance to the nearest established tree in meters. to an established tree decreased. Transplanted trees farthest from established trees $(24.9 \mathrm{~m})$ had trunks approximately twice as large as those closest to established trees $(10.7 \mathrm{~m})$.

Trunk diameter of transplanted trees had a close negative relationship with distance from the cut stump (Fig. 2). Trees planted closest to the stumps $(3.6 \mathrm{~m})$ had trunks over twice as large as those planted $28.7 \mathrm{~m}$ from the stump.

Leaf elemental concentrations of N, K, $\mathrm{Ca}$, and $\mathrm{Zn}$ were unaffected by tree type or distance from the stump or established tree (data not shown). Leaf P concentration was greater in seedling than nursery-grafted trees $(0.131 \%$ vs. $0.125 \% ; P=0.02)$, but distance from the stump or tree did not affect leaf $\mathrm{P}$. Leaf $\mathrm{Mg}$ was curvilinearly related to the distance from the stump $(0.30 \% \mathrm{Mg}$ at $3.6 \mathrm{~m}$ and $0.38 \%$ at $28.7 \mathrm{~m} ; \hat{\mathrm{Y}}=0.34-0.0123 \mathrm{~S}+$ $0.000479 \mathrm{~S}^{2} ; P=0.0001$ where $\hat{\mathrm{Y}}$ is the $\mathrm{Mg}$ concentration and $\mathrm{S}$ is the distance to the stump in meters). Tree type and distance to the nearest established tree did not affect leaf $\mathrm{Mg}$ concentration. There was a positive, linear relationship between leaf Fe concentration and distance to a stump $\left(54 \mu \mathrm{g} \cdot \mathrm{g}^{-1} \mathrm{Fe}\right.$ at $3.6 \mathrm{~m}$ and $59 \mu \mathrm{g} \cdot \mathrm{g}^{-1} \mathrm{Fe}$ at $28.7 \mathrm{~m} ; \stackrel{\mathrm{Y}}{=}=54+$ $0.223 \mathrm{~S}, P=0.007$ where $\hat{\mathrm{Y}}$ is the leaf $\mathrm{Fe}$ concentration and $\mathrm{S}$ is the distance to the nearest stump in meters), but other independent variables did not affect leaf Fe concentration. A significant interaction was detected between tree type and distance to the nearest established tree affecting leaf Mn concentration. Nursery-grafted trees nearest an established tree had $1184 \mu \mathrm{g} \cdot \mathrm{g}^{-1}$ leaf $\mathrm{Mn}$, decreasing to $774 \mu \mathrm{g} \cdot \mathrm{g}^{-1}$ leaf Mn $24.9 \mathrm{~m}$ from an established tree. Seedling trees had $586 \mu \mathrm{g} \cdot \mathrm{g}^{-1} \mathrm{Mn}$ nearest an established tree, increasing to $1447 \mu \mathrm{g} \cdot \mathrm{g}^{-1}$ leaf $\mathrm{Mn}$ when seedlings were $24.9 \mathrm{~m}$ from an established tree.

\section{Discussion and Conclusions}

Pecan trees transplanted into areas where crown gall was obvious on existing trees and stumps apparently did not contract crown gall. Crown gall normally becomes symptomatic within 2 to 4 weeks of infection (Moore, 2002). Temperatures below $15^{\circ} \mathrm{C}$ at the time of infection typically delay symptom development until the next growing season. Arnett and Schaad (1978) tested a non-gall-forming bacteria as a biological control for crown gall on pecan. One of their experiments consisted of planting young pecan trees, either soaked in a non-gallforming bacterial suspension or not treated, between two rows of established trees infected with crown gall. Galls did not develop on treated or non-treated transplanted trees. Similarly, English walnut transplants that were not infected with crown gall in the nursery were unlikely to become infected when transplanted into the field although crown gall was present (Epstein et al., 2008).

The high incidence of crown gall in old Georgia pecan orchards (Bouzar et al., 1983) may be the result of planting trees infected with crown gall in the nursery (Cole, 1969). In English walnut, seedborne A. tumefaciens inoculum increased as a function of the time seed were in contact with the orchard floor (Kluepfel et al., 2010). Seed inoculated with A. tumefaciens produced seedlings with galls in the absence of wounding. Contaminated seed may be a significant source of crown gall in nursery-grown trees. Another factor contributing to the high incidence of crown gall in older trees was frequent disking for weed control that wounded roots creating avenues for infection. In this study, transplanted trees had no crown gall symptoms and the orchard floor was managed with herbicides and mowing; thus, frequent wounding of roots was eliminated. We conclude that current nursery practices to ensure crown gall-free trees and orchard floor management that avoids wounding roots and spreading A. tumefaciens inoculum minimize crown gall infections.

Suppression of transplanted tree growth by existing trees was expected. However, growth enhancement of transplanted trees by stumps was unexpected. When this trend was discovered, field observations confirmed the dramatic growth enhancement of trees near stumps. Although decaying stumps provide certain essential nutrients for transplants (Harmon et al., 1986), leaf samples collected from 7-year-old transplanted trees did not clearly indicate a nutritional advantage supporting the enhanced growth. Naturally regenerating loblolly pine (Pinus taeda L.) stands 16 years after clear cutting had greater biomass production within $1 \mathrm{~m}$ of stumps than those $3 \mathrm{~m}$ from stumps (Van Lear et al., 2000). Improved growth was attributed to microsites with enhanced fertility, aeration, and moisture from decomposing roots that benefited growth of nearby trees. Stump removal or retaining stumps in place had minimal effects on subsequent performance of Citrus transplants in an established orchard (Futch et al., 2008).

Conclusions from this study include 1) a clear advantage for leaving stumps to promote rapid growth of transplants; 2) minimal risk of contracting crown gall by transplanted trees if the nursery stock is crown gall-free and orchard floor management avoids wounding tree crown or roots; and 3) growth suppression of the transplant is proportional to the distance from the nearest established tree.

\section{Literature Cited}

Arnett, J.D. and N. Schaad. 1978. Biological control of crown gall. Proc. Southeastern Pecan Growers Assn. 71:83-84.

Bouzar, H., L.W. Moore, and N.W. Schaad. 1983. Crown gall of pecan: A survey of Agrobacterium strains and potential for biological control in Georgia. Plant Dis. 67:310-312.

Cole, J.R. 1969. Control of crown gall, Agrobacterium tumefaciens, on pecan. Plant Disease Reporter 53:712-713.

David, D.J. 1958. Determination of zinc and other elements in plants by atomic-absorption spectroscopy. Analyst (Lond.) 83:655-661.

DeCleene, M. and J. Deley. 1976. The host range of crown gall. Bot. Rev. 42:389-466. 
Draper, N.R. and H. Smith. 1966. Applied regression analysis. Wiley, New York, NY.

Epstein, L., S. Kaur, J.R. McKenna, J.A. Grant, W.H. Olson, and W.O. Reil. 2008. Crown gall can spread between walnut trees in nurseries and reduce future yields. Calif. Agr. 62:111115.

Formica, J.V. 1989. Crown gall neoplasms, p. 497-512. In: Sirica, A.E. (ed.). The pathobiology of neoplasia. Plenum Publishing, New York, NY.

Foshee, W.G., III, R.W. Goodman, M.G. Patterson, W.D. Goff, and W.A. Dozier, Jr. 1997. Weed control increases yield and economic returns from young 'Desirable' pecan trees. J. Amer. Soc. Hort. Sci. 122:588-593.

Futch, S.H., J.H. Graham, and L.W. Duncan. 2008. Citrus tree removal method does not affect performance of reset trees. HortTechnology 18:559-562.

Gammon, N. and R.H. Sharpe. 1956. Mouse-ear: A manganese deficiency of pecans. Proc. Amer. Soc. Hort. Sci. 68:195-200.

Goff, B. and C. Browne. 2004. A method of dealing with overcrowded orchards. Proc. Southeastern Pecan Growers Assn. 97:77-82.

Harmon, M.E., J.F. Franklin, F.J. Swanson, P. Sollins, S.V. Gregory, J.D. Lattin, N.H.
Anderson, S.P. Cline, N.G. Aumen, J.R. Sedell, G.W. Lienkaemper, K. Cromack, Jr., and K.W. Cummins. 1986. Ecology of coarse woody debris in temperate ecosystems. Adv. Ecol. Res 15:133-302.

Kluepfel, D.A., A.E. McClean, L.E. Yakabe, M.M Maccree, and S.R. Parker. 2010. Detection and implication of early Agrobacterium tumefaciens infection of Paradox seeds and seedlings. Acta Hort. 861:497-500.

Moore, L.W. 1976. Latent infections and seasona variability of crown gall development in seedlings of three Prunus species. Phytopathology 66:101.

Moore, L.W. 2002. Disease caused by a bacterium: Crown gall, p. 10-11. In: Teviotdale, B.L., T.J. Michailides, and J.W. Pscheidt (eds.). Compendium of nut crop diseases in temperate crops. APS Press, St. Paul, MN.

Olsen, S.R. and L.E. Sommers. 1982. Phosphorus, p. 404-430. In: Page, A.L., R.H. Miller, and D.R. Keeney (eds.). Methods of soil analysis. Part 2. Chemical and microbiological properties. Amer. Soc. Agron. and Soil Sci. Soc. Amer., Madison, WI.

Reil, W.O. 2001. Comparison of Chandler walnut grown on both Paradox and northern California black walnut rootstock that were planted as seed, seedling or grafted trees. Acta Hort. 544:481-488

Sparks, D. and J.A. Payne. 1977. Freeze injury susceptibility of non-juvenile trunks in pecan. HortScience 12:497-498.

Thompson, T.E., R.E. Hunter, G.D. Madden, and E.J. Brown. 1982. A comparison of four methods of pecan orchard establishment. HortScience 17:972-973.

U.S. Department of Agriculture. 2009. 2007 Census of Agriculture. Natl Agri. Stat. Ser. Washington, DC.

Van Lear, D.H., P.R. Kapeluck, and W.D. Carroll. 2000. Productivity of loblolly pine as affected by decomposing root systems. For. Ecol. Mgt. 138:435-443.

Wells, L. 2013. 'Same old things' won't work in a changing industry. Pecan South 45:4, 10 .

Wood, B.W., C.C. Reilly, and A.P. Nyczepir. 2004a. Mouse-ear of pecan: I. Symptomatology and occurrence. HortScience 39:87-94.

Wood, B.W., C.C. Reilly, and A.P. Nyczepir. 2004b. Mouse-ear of pecan: II. Influence of nutrient applications. HortScience 39:95-100.

Yoemans, J.C. and J.M. Bremner. 1991. Carbon and nitrogen analysis of soils by automated combustion techniques. Commun. Soil Sci. Plant Anal. 22:795-807. 